\title{
Technologies, challenges and perspectives of biogas production within an agricultural context. The case of China and Africa
}

\author{
Rufis Fregue Tiegam Tagne ${ }^{1} \cdot$ Xiaobin Dong $^{2} \cdot$ Solomon G. Anagho ${ }^{1} \cdot$ Serena Kaiser $^{3}$. \\ Sergio Ulgiati ${ }^{3,4}$
}

Received: 7 August 2020 / Accepted: 28 January 2021 / Published online: 28 February 2021

(C) The Author(s) 2021

\begin{abstract}
The use of fossil fuels in modern economies has been a success because of the low cost of fossil resources. However, the depletion of fossil reserves, the increase in waste production and global warming concerns have led to increased research on the production of biofuels from renewable resources. Waste production is steadily increasing in quantity and constantly changing in quality, creating enormous risks for the environment and, consequently, for the health of the population. This situation is much more worrying in developing countries, in particular because of the considerable delay in the field of the conversion and recovery of biomaterials, due to their difficulty in approaching the problem in a way that fits their context. The composition of such wastes and residues, rich in organic matter, allows their conversion via biochemical mechanisms, thus constituting an effective solution to address the environmental problems of their disposal. Anaerobic digestion remains a valuable and effective technology for transforming these biomaterials into biogas. The present review focuses on technologies, challenges and areas of application of biogas, especially in China and some African countries, in order to promote the large-scale use of biogas for electricity generation and biofuels. Results point out that China is more used to this technology, while African countries still rely on traditional and less advanced technologies, thus hampering the potential derived from the large availability of biomaterials. Both realities, however, share similar backgrounds about the dimension of the biogas plants and their non-commercial purposes, even if China is recently shifting toward the adoption of a different model. These considerations are used in the article to open an interesting new scenario of political alternatives which may provide a way out from poverty and economic dependence, within the framework of a wider circularity.
\end{abstract}

Keywords Biogas · Biomass energy · Sustainable technologies · Waste to energy · Anaerobic digestion $\cdot$ Energy and development

Xiaobin Dong

xbdong@bnu.edu.cn

Sergio Ulgiati

sergio.ulgiati@uniparthenope.it

Extended author information available on the last page of the article 


$\begin{array}{ll}\text { Abbreviations } \\ \text { COP } & \text { Conference Of the Parties } \\ \text { NDRC } & \text { National Development and Reform Commission } \\ \text { kWh } & \text { Kilowatt hour } \\ \text { NGOs } & \text { Non-governmental organizations } \\ \text { BIOMA } & \text { Biogas Institute of Ministry of Agriculture } \\ \text { BPPA } & \text { Biogas Partnership Program in Africa } \\ \text { PRC } & \text { People Republic of China } \\ \text { IEA } & \text { International Energy Agency } \\ \text { SNV } & \text { Netherlands Development Organization } \\ \text { IITA } & \text { International Institute of Tropical Agriculture } \\ \text { PANERP } & \text { National Energy Action Plan for Poverty Reduction } \\ \text { TIPEE } & \text { Information Processing for Energy Policies for Ecodevelopment } \\ \text { GHG } & \text { Greenhouse gas } \\ \text { ADEME } & \text { French Environment and Energy Management Agency } \\ \text { AD } & \text { Anaerobic digestion } \\ \text { BOD } & \text { Biological oxygen demand } \\ \text { HYSACAM } & \text { Cameroonian Society of Hygiene and Sanitation }\end{array}$

\section{Introduction}

Sustainable development is currently one of the most up-to-date concepts in the debate between developed and developing countries, as most of these countries have focused on their economic growth while neglecting the imperatives of environmental protection. With the expression "sustainable development" it is meant the use of the available resources without jeopardizing the well-being of future generations (Bertrand and Rocher 2007).

Thus, at COP 21, member countries of the United Nations set as their objective to reduce their carbon emissions by $30 \%$ by the year 2030 compared to those of 1990 , and to reach the carbon neutrality in 2100 (United Nations 2015). In the same direction, the Chinese authorities are prioritizing the reduction of greenhouse gas emissions, with the declared goal of reducing global warming. One of the solutions to the carbon emission problem is to develop renewable energies as alternatives to fossil fuels. Among the alternative energy sources, lignocellulosic and waste biomasses are considered carbon-neutral fuels because the $\mathrm{CO}_{2}$ released from their combustion is integrated into the virtuous cycle of photosynthesis of plants (US Environmental Protection Agency 2015). Agricultural waste-to-energy bioconversion technology can make a significant contribution to electricity demand relative to fossil fuel supply (Nixon et al. 2017). These agricultural wastes can be assimilated to woody material, animal excrement, manure and associated wastewater (Almomani et al. 2019).

These biomaterials can be transformed by technological processes to obtain biochemicals and bio-energies, among which biogas can be used as a biofuel or for electricity production (Pan et al. 2018). Biogas is produced by anaerobic digestion, a process that decomposes organic matter, using a set of microorganisms in anaerobic conditions, to produce biogas and digestate (Yang et al. 2015). Anaerobic digestion technology is a biochemical process used for the biological treatment of wastes producing sustainable energy and reducing greenhouse gas emissions (Almomani and Bhosale 2020). 
Biogas is considered as renewable energy because it comes from organic waste that would not be valued elsewhere. Biogas production is therefore part of a circular economy. It can be upgraded locally to produce electricity, heat or both simultaneously in combined cycles. The use of biogas in the place of fossil fuels as energy source in industries gives rise to a much more eco-friendly, carbon-free and sustainable environment (Wall et al. 2018). Industries and households are continuously using biogas for heating and for producing hot water. Food industries requiring very clean fuel, whose combustion does not generate odors and particles, are increasingly using biogas. In many low- and middle-income countries of Africa and Asia, biogas produced in small digesters is used in rural areas for heating, cooking or lighting (Lohri et al. 2017). Biomethane can be used in other applications, such as catering, industrial kitchens and bakeries, where the heating has to be instantaneous and continuous and needs to be rapidly controlled.

Biogas in a non-enhanced form is obtained from cogeneration and trigeneration processes and can be used in power plants to generate heat and electricity, to power absorption chillers for cooling purposes (Kaparaju and Rintala 2013; Persson et al. 2014). Electricity from the power plants can be used locally, or it may be provided to the electricity network or grid, as well as for district heating. Thus, the use of heat from the combustion of biogas brings in very important economic and environmental benefits as it is renewable (Hengeveld et al. 2016) and suitable for several purposes.

Biogas is also used as vehicle fuel, after treatments to remove hydrogen sulfide, dust particles and $\mathrm{CO}_{2}$, generating biomethane with increased energy content. The improved clean biogas is used as fuel for cars, buses and trucks of different sizes. Several countries present well-developed infrastructure for gas vehicles, and it is possible to easily refuel natural gas powered vehicles (Florio et al. 2019). The upgraded biogas is completely interchangeable with its fossil equivalent. The real challenge for the transport sector lies in the abandonment of fossil fuels and the decarbonization of energy.

Fuel cells are another potential use of biogas to produce heat and energy. Biogas steam reforming generates "green" hydrogen (Minh et al. 2018). Fuel cells combine hydrogen with oxygen from air to produce electrical energy and co-product water vapor and heat (Erin 2019; Zucaro et al. 2013). Fuel cells are recognized as very reliable tools and are often used as an emergency power source. Cogeneration systems with fuel cells (Bargigli et al. 2010) are presently used in hospitals, campuses, and remote telecommunication stations to generate heat and electricity, but also for transportation and as an electric generator in some residential homes.

China's energy generation has increased rapidly since 1980 . However, demand is more and more outstripping supply because of the vast size of the country, where it is difficult to bring energy to remote and isolated rural areas. According to data from the National Development and Reform Commission (NDRC), total electricity production increased by 6.5 percent in 2017 to 6.310 billion $\mathrm{kWh}$ (John and Mathewsand 2016). This energy is obtained mainly via coal combustion, which provides the bulk of the energy, delivering about $66 \%$, of the total energy consumption of the country. The second source is oil and other liquid fuels accounting for nearly $20 \%$ of consumption, hydroelectric sources (8\%), natural gas (5\%), nuclear energy (nearly 1\%) and additional renewable energies (more than 1\%) (María 2018). Concerning renewable resources, China has huge amounts of residues generated from agricultural activities and forest exploitation. These agricultural wastes contain materials like cellulose, hemicellulose and lignin which biodegrade and can be easily digested in the process of anaerobic digestion (Almomani 2020). It also generates large amounts of animal manure and municipal solid waste. All of these can be used as raw materials for producing biogas. It can be noticed that these "natural resources" do not 
compete with food items for which the cost keeps rising, especially that of staple foods. China is considered the first country in terms of agricultural production: It produces wheat, rice, potatoes, peanuts, millet, cotton and more. Also, livestock is the second most important component of agricultural production in China (Xuchuan et al. 2018) as it is the largest producer of hogs, chickens and eggs in the world. As an example, Fushan Farm located in Hangzhou in Zhejiang Province is composed of 32.47 hectares of rice, 4 hectares of tea bushes, 13.7 hectares of aquatic protection and 7.3 hectares of ponds for fish farming. The farm also produces 30,000 egg laying hens, 150,000 broilers and 8000 pigs each year; this results in a daily spill of 15 tons of solid waste and 70 tons of wastewater, thereby representing a huge amount of pollution (Zhang et al. 2015). These main products that can be consumed, marketed or processed by agro-food industries create enormous quantities of waste that are most often removed by open burning or by natural decomposition for a long time (Rufis et al. 2019).

Similar problems also arise in Africa, where electrification levels are still significantly low, compared to the population growth and barely reaching 42\% (Vintila et al. 2019). By 2050 , the continent will have a population of at least 2 billion people, $40 \%$ of whom will live in rural areas. In 2010, almost $57 \%$ of the population of Africans did not have access to electricity (État des Villes Africaines 2010). In sub-Saharan Africa, more than 600 million people do not have access to electricity supply, and the situation will substantially remain constant until 2030, if nothing changes (Joseph et al. 2019). Cameroon, like many other sub-Saharan African countries, is still facing a significant problem of access to electricity. For example, in Cameroon, only 3 million of its 20 million inhabitants have access to electricity at a rate of $15 \%$. Total electricity production in Cameroon is around $305 \mathrm{kWh}$ per inhabitant for a gross electricity consumption of $6.2 \mathrm{TWh}$ (Vintila et al. 2019). Yet the country has abundant resources which may become renewable energy sources and may also play a major role in supplementing the growing energy demands, while also contributing to socioeconomic development. Cameroon is an important subregional agricultural player, where the rural sector is a driving force of the national economy, ensuring the food security of population in a concern for sustainable development. It mainly produces maize, millet, sorghum, rice, cassava, macabo, taro, yam, sweet and Irish potatoes, peanut, bean and soy, hence producing huge waste. Their management may add value to the national economy (Vintila et al. 2019). In the interest of sustainable development, the adoption of renewable energy is an important issue for many developing African countries. In addition, biogas could be a fast remedy to fix the pressure arising from low electrification of rural communities, by burning it to generate power at a low cost. The depletion of fossil fuels, the increase in agricultural residues, the threats from the accumulation of municipal waste, and the need for a sustainable environment and sanitation all justify the urgency to set up improved biogas technologies.

This work will mainly focus on a comparison of biogas energy technologies and challenges in China and Africa. The study stems from the interest of Africa and China in the technology of biogas as a multipurpose provider of energy for the production of sustainable fuel, electricity, heat and fertilizer. Biogas production and use show benefits in the environmental (less greenhouse gas emission), economic (low cost of produced commodities), sociocultural (employment) and legal-institutional (standards and regulations) sectors.

Of course, creating a comparison between China and selected African countries may raise some problems in terms of dimensions, industrialization and economic strategy and orientation, but this paper does not intend to make comparisons in absolute terms: What is interesting is the similarity in the role of agricultural production, as well as the similar growing demand of electrification and the wide part of population still excluded 
from it because living in rural areas. These similarities suggest that the path that China is following toward the adoption of more renewable energies may be a solution for African countries, too. Following the development of policies for biogas production in China and how they were integrated within the existing economic systems (agriculture, industry, etc.), similar or diverging and revised pathways could be traced for the development of the biogas technologic and regulatory systems in Africa. In this perspective, Cameroon is chosen as a case study of existing technologies and variables. This work is not comparing absolute numbers of totally different contingencies, but aims at establishing an example of development of suitable strategies.

\section{Methodology and historical background}

\subsection{The biogas technological background in China and Africa: an historical perspective}

In China, as well as in Africa, the implementation of biogas production has been very much small-scale oriented so far, being the total amount of biogas production mainly represented by small plants located in remote areas where there is no connection to the national electric grid. This means that the biogas production had no commercial purpose until a recent shift, while the American and European contexts have developed almost exclusively commercial large-scale production (Kemausuor et al. 2018). However, as anticipated above, China has recently changed its direction, and is now adopting a more commercial-oriented strategy (Kemausuor et al. 2018).

So, on the one hand, we have a similar development of biogas production in China and in the African continent. On the other hand, it is important to consider the recent Chinese shift and the level of top-down organization of the Chinese context, which surely represents an easier management of any modification in the political choices about energy.

Leaving aside the considerations about how desirable this centralization can be from the democratic point of view, it is all the same possible to accept that African countries may be inspired by the Chinese experience: Governments may use renewable sources as an opportunity to regain the control of strategic sectors.

In this sense (production of biogas through anaerobic digestion), widening the proportions of biogas plants may become interesting for African countries which, on the contrary, now mainly rely on foreign private investors for renewable energies: As a matter of fact, currently there is a wide profit which very seldom provides advantages to the countries and the continent (IEA 2018).

It may seem a paradox, but the "Chinese lesson" could represent a way for Africa to gain more economic independence from many ex-colonial countries and from China itself, which is currently one of the main economic investors in Africa. However, it is important to specify that the current link between China and Africa in the energy field is more related to the purchase of Chinese coal by the African countries: Chinese investments in Africa are more concentrated within the field of services than in renewable energies (Chen et al 2018). In this regard, we can be more precise concluding that the possibility of investing in bigger biogas plants represent the opportunity for African countries to become both more independent from the European ex-colonial countries' investments in renewable energies and from the necessity to buy coal from China. 
One of the examples we may consider to analyze the management of a larger biogas implementation in China is represented by the "Hebei Rural Renewable Energy Development Project," started in 2015 and lasting until 2021 for sustainable biogas production and utilization. It includes a large-scale biogas facilities management with six installations in Hebei region for the conversion of agricultural wastes into stable clean energy for rural residents (https://projects.worldbank.org). From the indicators published by the World Bank, the project has allowed access to biogas supply to 2,300 rural households and is expected to create access to further 58,780 households by the end of December 2020. The biogas production has also generated a wide reduction in $\mathrm{CO}_{2}$ emissions (https://www.worldbank. org/en/results) and this indicator is expected to grow, as well. This project may be a good example of introduction of new criteria in clean energy production, to involve external investments in a way which contributes to the improvements of local communities, within a productive interplay of central Government planning and the due importance to the territorial dimension.

This study was conducted with reference to the technologies of installed biogas digesters, the problems and challenges envisaged between China and Africa. China has developed and used biogas technology for almost three centuries so far (Lei et al. 2016). Since the 1980s, its government has integrated the development of biogas technology into the national program (Jiang et al. 2011). The capacity of biogas production in China by domestic digesters ranged from 4.5 Giga cubic meters to 16 Giga cubic meters between 2003 and 2013, reaching 8000 Ktoe oil equivalent. In recent years, the Chinese have introduced various models of biogas digesters of different categories, depending on the circumstances of local environment. The main contributor to biogas production in China is rural biogas plants. The round pressure biogas plant was the oldest form of biogas digester used, and it was the most popular amongst the Chinese farmers. In recent years, other forms of digesters have been developed, an example of which is the Strong back-flow biogas digester (He et al. 2013). About 40 million digesters have been installed in China, while each year, 6 million are planned to be constructed, each using a totally or partially prefabricated fixed dome design. On the international scene, the use of prefabricated hybrid technology seems to be on the rise because it can be rapidly be installed, and it has the advantage of being able to be readily recovered by investors in the event of non-repayment of loans. However, there are very few reports on studies related to the technological innovations of large-scale biogas engineering projects in China. Actually, most of the high-level biogas engineering technology in China comes from developed countries (Lei et al. 2016).

Africa is currently undergoing rapid economic growth, sustained transformation, rapid population growth and diversified economic activities. For the growth to be sustainable, massive investments in the energy sector are required. The current rate of power production in Africa is very low (33\% less than China), especially in the countries of the subSaharan Africa region (IAE 2019). Figure 1 shows the production of electricity in China and Africa broken down into different primary sources. It can clearly be seen that, while coal dominates the primary energy supply in China, biomass is still the main power source in Africa (although fossil contribution is also relevant).

Natural resources such as biomass in Africa are still exploited in traditional ways, because of little or no policies on biomass energy and also due to very low levels of investment. The biogas technology emerged in Africa in recent decades has been supported by projects and the training of technicians (Cyimana et al. 2013). But this technology is characterized in Africa by low level of access, low capacity in utilization and lack of maintenance. With the help of NGOs, several countries like Rwanda, Ethiopia and Tanzania have developed more than 17,000 digesters between 2007 and 2012 (Cyimana et al. 2013). Some 


\section{Electricity production in China in 2017: 2449472 Ktoe}

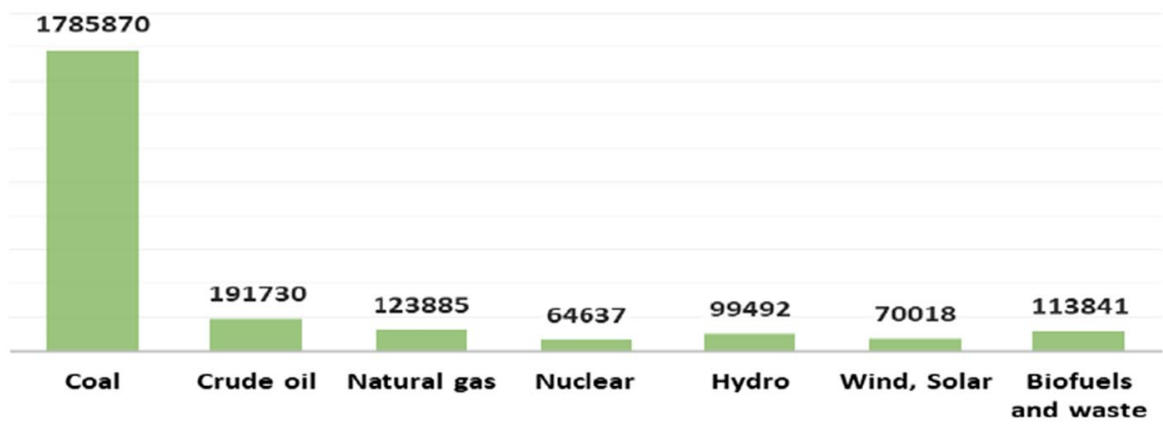

\section{Electricity production in Africa in 2017: 812010 Ktoe}

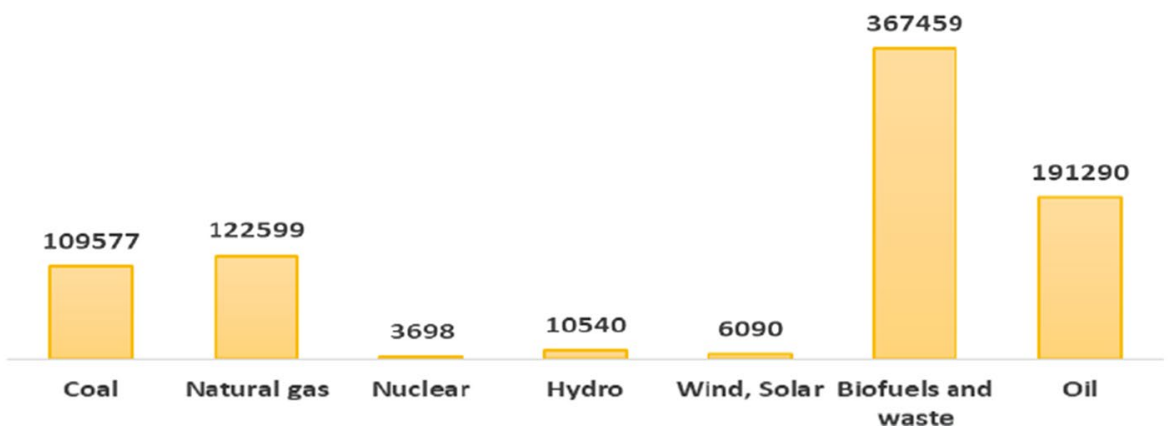

Fig. 1 Production of electricity in China and Africa from different sources in 2017 (IEA 2019)

countries such as Morocco, Tunisia and Botswana, which are near to deserts and hence have unfavorable geographical positions, have been engaged on installing biogas digesters. Currently, South Africa runs about 200 working biogas digesters (Patrick et al. 2016). This shows that biogas technology is undergoing considerable development in Africa. Many African countries such as Burundi, Botswana, Burkina Faso, Ivory Coast, Ethiopia, Ghana, Guinea, Lesotho, Namibia, Nigeria, Rwanda, Zimbabwe, Tunisia, Cameroon, Morocco, Tanzania, and Uganda have developed and installed large-sized and medium-sized domestic biogas digesters to address the energy crisis in their territories (Amigun et al. 2012). Slaughterhouse waste, industrial waste, agricultural residues, household waste and animal excrement are used as raw materials in these various digesters (Mshandete and Parawira 2009). Figures 2 and 3 show some digesters used, respectively, in Africa and China (Patrick et al. 2016). Since 2008, several partnership programs have taken the initiative to support biogas projects in Africa. For example, China (BIOMA), provides technical support to national biogas programs (Renwick et al. 2007) even if, as said above, this does not represent the main investment field for China in Africa. This firm has trained several experts and technicians in the domain of biogas from a number of African countries. Countries such as Senegal, Burkina Faso, Ethiopia, Tanzania, Uganda and Kenya, which belong to the Biogas Partnership Program in Africa (BPPA), have built 70,000 biogas digesters in 2013, 

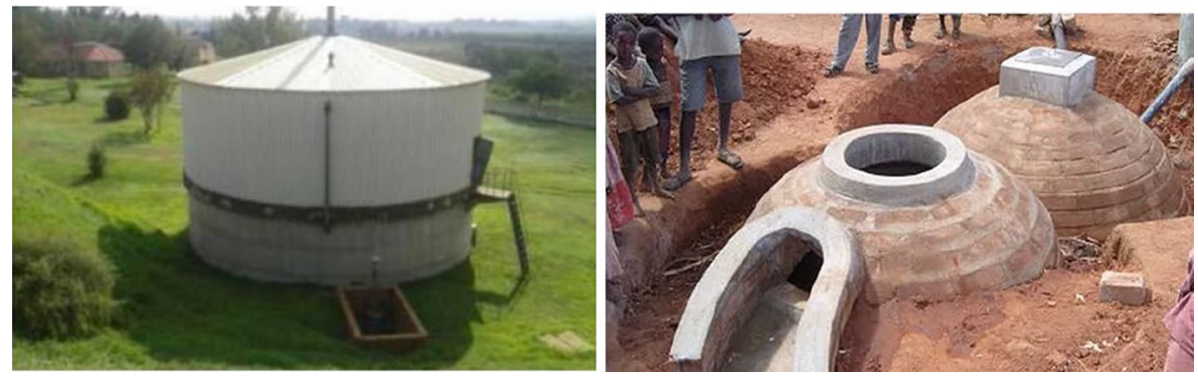

Fig. 2 Examples of digesters used in Africa
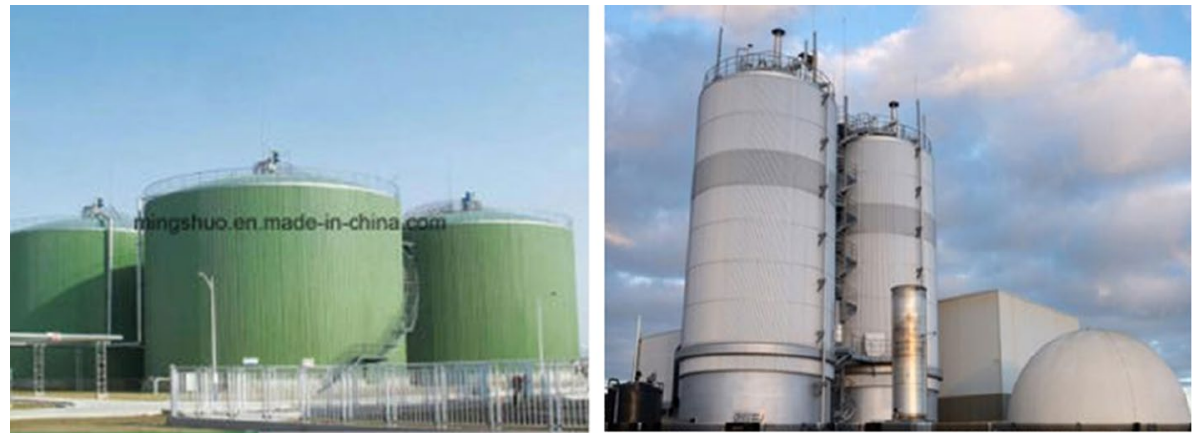

Fig. 3 Examples of digesters used in China

funded by Netherlands (Clemens et al. 2018). Because of national biogas programs, there is a rapid increase in the number of biogas plants in Africa. These national programs were born in countries such as Rwanda, Tanzania, Kenya, Uganda, Ethiopia, Cameroon, Benin and Burkina Faso. These states aim at building more than 10,000 biogas digesters in the coming years (Clemens et al. 2018). However, to maintain the rapid growth in the number of digesters and deal with technical, environmental, financial and social issues, there is the crucial and urgent need to provide scientifically rigorous answers to questions such as available substrates, efficiency, technology development, and personnel training.

Moreover, as already said, showing the positive consequences of the investments in biogas, this article aims at supporting the idea that governments should rely more on their own resources and ventures, thus creating the conditions for a wider independence from investors and raw materials coming from abroad.

\subsection{Biogas technologies in China and in Africa}

The biogas currently produced in China is mainly used for the production of heat, electricity, and compost for fertilization. Biomethane from biogas upgrading is used today in China in vehicles as biofuel (Deng et al. 2017).

Household biodigesters are the most widely used in Africa, as said above. The biogas currently produced in Africa is used for cooking and lighting. Digestate is used as a 
fertilizer for soil fertilization and as a pesticide for the protection of crops against pests and other harmful insects (EDE 2013).

The People's Republic of China (PRC), located in Eastern Asia, covers an area of about 9.6 million $\mathrm{km}^{2}$. It is the third largest country in the world, with only Russia and Canada being bigger than it. It is the most populous state on the planet, with nearly 1.4 billion inhabitants. It shares borders with many countries: Russia and Mongolia in the North, North Korea in the East, Vietnam, Laos, Burma (Myanmar), India, Bhutan and Nepal in the South, Pakistan, Afghanistan, Tajikistan, Kyrgyzstan and Kazakhstan in the West. The Chinese population is still very rural. In 2018, the density of the Chinese population was 148.35 inhabitants per $\mathrm{km}^{2}$ (World Bank 2020). China ranks second in economic power in the world. Its economy is mainly based on agriculture, manufacturing and energy. It is the largest producer and consumer of energy. Energy is very vital for the economic development of all countries. The gross electricity consumption in China averaged $6990 \mathrm{TWh}$ in 2018.

The fossil fuel reserves and domestic production capacity remain insufficient in front of the colossal demand of the population (John and Mathewsand 2016). China relies a lot on oil and gas it imports from the Middle East and Africa. They are mostly transported by oil tankers along maritime shipping lines to meet the demand of the population. This strong dependence of the country on foreign oil, the problems associated with the environment due to the massive use of coal, and the need to fight against climate change have oriented the Chinese energy strategy toward a greater diversification of the energy mix and increased the use of renewable energy (Zhang and Zhang 2014). Today, China faces a challenge: continuing its economic growth to improve the life of its 1,380 million inhabitants and meet their expectations, but at the same time reducing pollution from coal and limiting its emissions of greenhouse gases. For this to occur, the Chinese government has set as a goal to increase the amount of non-fossil energy to at least $15 \%$ of the national energy consumption by 2020 and 20\% by 2030 (John and Mathewsand 2016). Among alternative sources to fossil fuels, biomass, which is organic matter, generally agricultural or forestry by-products that can be used directly to produce heat by combustion or indirectly, after having been transformed into various biofuels, is considered to be predominant.

Africa, the second largest continent in the world, accounts for $10 \%$ of the world's population (Amigun et al. 2008). In this respect, biofuels, in particular biogas, are considered as the most powerful alternatives to fossil fuels (Adeniyi et al. 2007; Ayhan 2008). Biogas production is highly developed in America, Asia, and Europe. However, the African continent and more specifically the sub-Saharan Africa region has experienced a very slow development of this technology in recent decades, despite significant efforts at the individual, institutional, national and international levels (Lynd et al. 2015). This delay is due principally to the lack of appropriate infrastructure and the limit on raw material caused by poor farming practices (USDA/FAS 2008).

\subsection{Methods used}

Many scientific works have already been published about biogas production technology. The various works cited within the framework of this study were listed in the sites available online (Academia. edu, Mendeley library) making an inventory on the potential production of biogas in Africa and China. Indeed, the present study took into account the scientific results and data published in journals and books and indexed in Scopus, Web of Science, Google Scholar and other databases available in internet between the years 2000 
and 2020. In addition, articles from UN, IEA, Chinese government and African governments are included. Selected articles make reference to anaerobic digestion technology in China and Africa. In total, 95 scientific works were referenced, most of which referred to in the following, distributed as follows:

- Articles: 50 published works

- Thesis: 3 published works

- World Bank: 2 published works

- UN: 2 published works

- IEA: 2 published works

- Book chapters: 5 published works

- Conference papers: 7 published works

- Conference reviews: 9 published work

- Book chapters: 8 published works

- Reviews: 15 published works.

About the political and economic framework, reports and articles from the World Bank databases have been used to support the idea that renewable sources of energy are taken into consideration even by international and supranational organizations as path for a development which is not only environmentally feasible, but also economically advantageous and fair.

Of course, this does not mean that the concept of what is fair about development is expressed by the values and purposes of the World Bank or other similar organizations, but the critical use of their databases can be a precious resource for researchers.

\section{Results}

\subsection{General results about China and Africa}

China holds important reserves of different types of biomass and biogas, uses less expensive and less devastating technologies: This pushes China to further develop biomass and biogas projects. China is currently the world leader in renewable energy. Biogas production in China is already widely used and can still be well developed to provide green energy. It is also a highly sustainable energy for the country. This form of energy accounts for about $1.2 \%$ of China's total energy consumption. In 2010 the Chinese Government set two main objectives: The first one was that 40 million households (about $16 \%$ of all rural households) would use biogas and their number was expected to double to 80 million by 2020 . In 2008, about 40 million digesters were in service for biogas production. The second was to combine biogas technology with agricultural production and environmental protection. The production of biogas is in perpetual evolution. According to the International Energy Agency (IEA 2019), the country produced 630 megawatts of biogas in 2018. Figure 4 shows the evolution of biogas production in People's Republic of China between 2010 and 2018 according to IEA (2019).

China has an abundance of biomass resources. Few of them are effectively used today. These resources are mainly obtained from forest residues, animal wastes, industrial and municipal biodegradable wastes. China produces about 700 million tons of straw a year, distributed as follows: About $37 \%$ of this total is maize, $28 \%$ rice and $20 \%$ wheat. The 


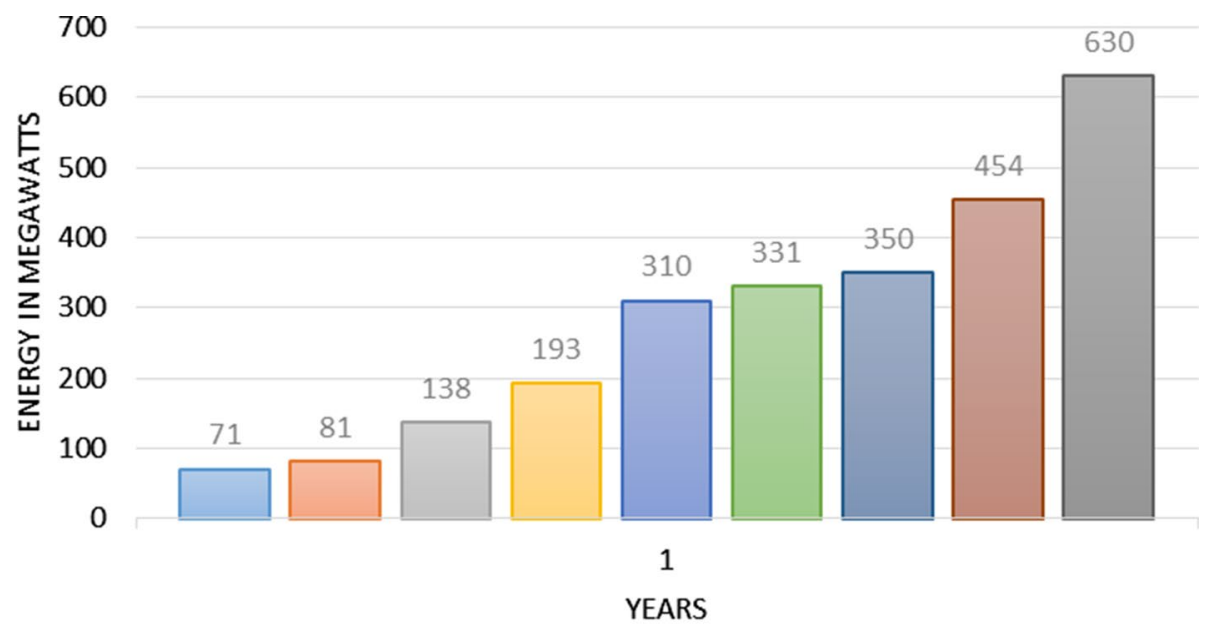

$\square 2010 \square 2011 \square 2012 \square 2013 \square 2014 \square 2015 \square 2016 \square 2017 \square 2018$

Fig. 4 Evolution of biogas production in China between 2010 and 2018 in Megawatt (IEA 2019)

remaining $15 \%$ is derived from various other crops. In addition, China produces 300 million tons of forestry waste, which is immediately useable for fuel production (Chi et al. 2017). The country is also expected to produce 210 million tons per year of municipal solid waste by 2020. It could produce between 2 to 10 billion cubic meters of methane if $60 \%$ of this municipal waste disposed of as for landfill were used for methane production. Table 1 gives the potential quantity of residues for biogas production (Liu et al. 2008).

China has been known for many years for its ability to use organic waste for biogas production. However, it is surprising that, despite the success of anaerobic digestion for the production of biogas, the application of biogas technology at relatively large scale for small communities is still essentially limited today. This limit can also be due to the lack of raw materials, because the widely available biomass in China is also used in the pulp and paper making industries. Yet the country has other resources that do not yet have any commercial value, like waste from hospitals such as food waste and sewage, unless already managed as municipal waste. Some authors indicate as potential substrates also body parts, blood, chemical drugs, medical devices and syringes, which are very rich in organic matter and can be used as feedstock for biogas production, although possibly raising ethical problems

Table 1 Available residues for biogas production in China

\begin{tabular}{ll}
\hline Feedstock & Amount (tonnes) \\
\hline Straw & 818 \\
Agricultural processing waste & 400 \\
Animal manure & 5800 \\
Solid waste & 120 \\
Wastewater & 5300 \\
Restaurant waste & $30-40$ \\
Sewage sludge & $30-35$ (wet) 11 (dry) \\
\hline
\end{tabular}


and lack of respect of local cultures (Mohammed et al. 2017). The number of hospital centers in China has increased dramatically from 305,000 to 961,830 in space of 10 years and consequently, medical waste has also increased rapidly ( $\mathrm{Li}$ et al. 2014). To enhance the biomass for large-scale application, careful management of hospital waste will increase the potential for biogas production.

According to Novozymes (Susan et al. 2016), China could become a world leader in the production of second generation $(2 \mathrm{G})$ biofuels. According to a report by the International Energy Agency, 2G biofuels account for about $90 \%$ of all biofuels used today. Thus, wastes could represent 2.4 to $2.8 \%$ of China's total energy consumption. China is now building new socialist villages under the current Eleventh Five-Year Plan (Lifan 2016). The guidelines for building such villages are the development of production system, maintaining a clean environment and innovation to save resources. The development of biogas production corresponds to that program. China has developed many types of household biogas digesters since the 1980s to overcome the weaknesses of traditional brick and concrete digesters (Lei et al. 2020). Among all the traditional digesters, the Chinese dome digester is the most popular one due to its reliability. It has become a standard for the design of domestic prefabricated digesters like the Puxin digester (Jegede et al. 2019). The most common prefabricated biogas digesters in China are flexible plastic digesters and composite material digesters (Lei et al. 2020). Flexible plastic digesters are very efficient due to their low cost and ease of implementation and use. Composite material digesters have many advantages, such as ease of movement, long-term durability and high productivity (Lei et al. 2020). The major constraint to the program is the lack of technical expertise in managing and maintaining the biogas digesters.

Biogas still remains an unknown energy source in some African countries, despite several attempts for its use that have been undertaken since the forties, also because it is not part of their sociocultural and economic context. A very limited number of African countries had adopted biogas technology in 2005 with a number of biogas plants, although insignificant compared to what was achieved on the other continents (Mshandete 2009). In an effort to improve biogas production in Africa, an African initiative was launched in 2007 to install biogas digesters in at least 2 million households by 2020 (Van Nes et al. 2007; Ukpabi 2008). Under this initiative, there was an increase in the number of biogas plants in 2010, with Tanzania alone having about 4000 units (Ocwieja 2010). However, only about $60 \%$ of these plants were functional, while the others displayed a lower level of satisfaction for reasons such as planning and construction errors, low awareness of the community and lack of an adequate culture of maintenance, (Ocwieja 2010). Composite material digesters are relatively new in African countries (Lei et al. 2020). Almost all African countries still use traditional brick and concrete digesters. Table 2 shows some African countries that had adopted biogas technology in 2005 (Mshandete 2009).

About $95 \%$ of the population in sub-Saharan Africa, uses traditional biomass for cooking and heating, with access to modern energy systems for cooking being very low. In North Africa a very low percentage, 10 million out of more than 200 million people, of population relies on traditional biomass. Biogas in Africa is produced by waste from agricultural activities (crops and livestock), bio waste from municipal activities and bio waste from agro-industrial activities. According to the World Bank report 2015, 62\% of the population of sub-Saharan Africa and 36\% of the population of North Africa live in rural areas, whose energy needs are very different from those of the urban population. A report by SNV and the International Institute of Tropical Agriculture, published in 2007, estimated the technical potential of national biogas plants in Africa at 18.5 million, while current ones are estimated at less than one hundred thousand. This scale and implementation model has 
Table 2 African countries with biogas producing digesters

\begin{tabular}{lll}
\hline Country & $\begin{array}{l}\text { Number of small/medium } \\
\text { digesters }\left(100 \mathrm{~m}^{3}\right)\end{array}$ & $\begin{array}{l}\text { Number of } \\
\text { large digesters } \\
\left(>100 \mathrm{~m}^{3}\right)\end{array}$ \\
\hline Botswana & $>100$ & 1 \\
Burkina Faso & $>30$ & - \\
Burundi & $>279$ & - \\
Egypt & $>100$ & $<100$ \\
Ethiopia & $>100$ & $>1$ \\
Ghana & $>100$ & - \\
Cote D'Ivoire & $>100$ & -1 \\
Kenya & $>500$ & - \\
Lesotho & 40 & - \\
Malawi & - & 1 \\
Morocco & $>100$ & - \\
Nigeria & Few & - \\
Rwanda & $>100$ & $>100$ \\
Senegal & $>100$ & - \\
Sudan & $>200$ & - \\
South Africa & $>100$ & $>100$ \\
Swaziland & $>100$ & - \\
Tanzania & $>1000$ & 1 \\
Tunisia & $>40$ & - \\
Uganda & Few & - \\
Zambia & Few & - \\
Zimbabwe & $>100$ & 1 \\
\hline & &
\end{tabular}

already been adopted in Asian countries, as China has about 40 million digesters. Biogas production could therefore constitute a viable means for overcoming the energy shortage in African countries, thus constituting a brake on social and economic development. The African continent with its hot climates and tons of waste generated could develop high performances in organic matter anaerobic digestion (Amigun et al. 2012). Table 3 gives some comparisons of the biogas situation in China and Africa.

\subsection{The case of Cameroon}

\subsubsection{The geography and energy situation of Cameroon}

As a Central African country, Cameroon is located between the 2nd and 13th degrees of north latitude and the 9th and 16th degree of east longitude. With a total area of $475,650 \mathrm{~km}^{2}$, of which $466,050 \mathrm{~km}^{2}$ are continental and $9600 \mathrm{~km}^{2}$ are maritime, its surface area is about $5 \%$ of the total surface area of China. It is open to the Atlantic Ocean over a distance of $280 \mathrm{~km}$. It is bounded to the north by Lake Chad, northeast by the Republic of Chad, to the east by the Central African Republic, to the south by the Republic of Congo, the Republic of Gabon and the Republic of Equatorial Guinea and to the West by the Federal Republic of Nigeria. This geographical location of Cameroon explains the diversity of natural environments, from pre-Sahel to the high western lands, through the coastal 


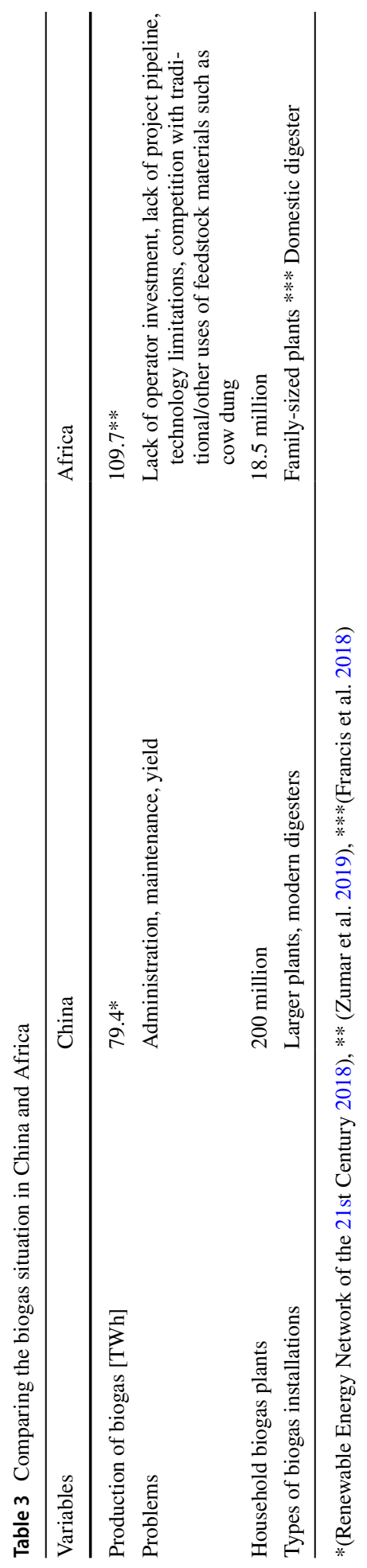


Fig. 5 Primary sources of energy in Cameroon in 2017 (\%) (IEA 2019)

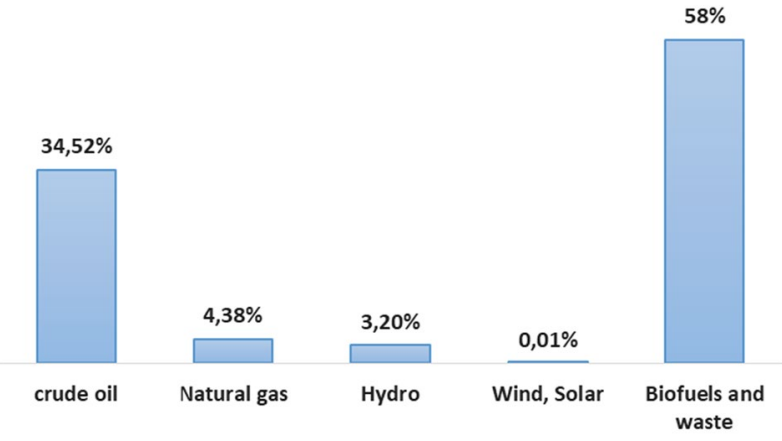

Fig. 6 Final uses of energy in Cameroon in 2017 (\%) (IEA 2019)

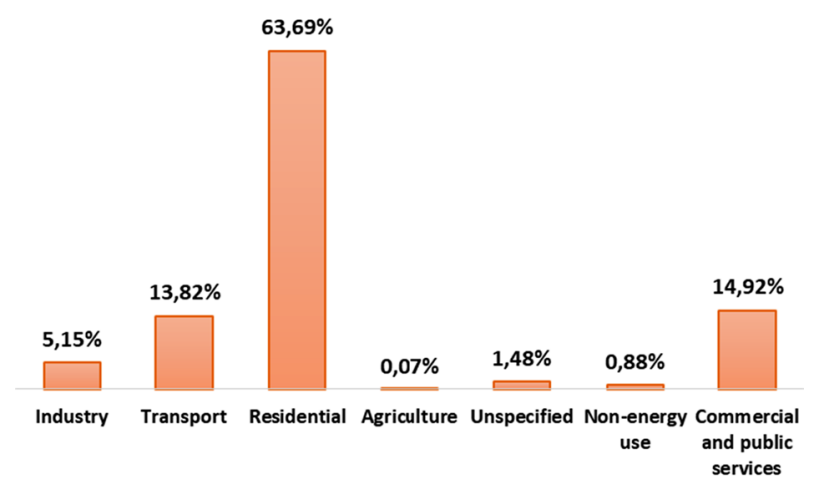

lowlands and the highlands of medium altitudes. This mosaic of natural environments justifies the variety of Cameroonian agricultural products (Tchatat 2014). Cameroon's population in 2015 was approximately 24 million, making it the most populous country in Central Africa. The Cameroonian economy is essentially based on agricultural activity (agriculture, livestock, fisheries and forestry) and oil (Yotchou 2014). Cameroon has substantial renewable energy resources such as solar, wind, biomass, geothermal and hydropower. Hydropower is the main source of energy used in industries with $75 \%$ of electricity generation and little attention is given to other renewable energies. Major sources of energy that the country has are coal, oil, hydro, and biofuels (EUEI-PDF 2013). Electricity production in 2017 in Cameroon was 11,295 ktoe, with 58\% produced mainly from biofuels and waste (IEA 2019). Figures 5 and 6 show, respectively, the main sources of primary energy and consumption in Cameroon in 2017 (IEA 2019).

The majority of the energy used in Cameroon comes mainly from the biomass resources originating from agricultural activities, livestock and food industries. Cameroon is recognized as the third country with the largest biomass in sub-Saharan Africa (Mus'ud et al. 2015).

Overall, Cameroon's energy consumption is more than $65 \%$ met by traditional energies (wood, coal, etc.), $21 \%$ by petroleum products and $14 \%$ by electricity according to National Energy Action Plan for Poverty Reduction (PANERP) (Ministry of Energy and Water Resources Cameroon, 2010). Nearly all poor households in Cameroon use firewood to meet their energy needs for cooking. Barely $6 \%$ of energy resources are exploited, while an important part of the households and partners of the industrial sector in the country do 
not have access to electricity and the available electric grid, which requires heavy investments, and is characterized by intermittent performance. The challenge of Cameroon's electrification program is to ensure an adequate supply of energy throughout the country at the lowest cost. The government aims by 2020 to achieve a national electrification rate of $48 \%$, an access rate of $75 \%$ electricity and a rural electrification rate of $20 \%$. This work can contribute to the achievement of these objectives. Although the consumption of wood poses enormous environmental and health problems, this energy resource remains the most consumed in the country. Table 4 tells us about the most polluting sectors in Cameroon. It shows that the combustion of fossil fuels is the main source of GHG emissions, followed by the transport sector.

Commercial production of biofuels is still not significant in Cameroon, although the objective of the Government of Yaoundé is to produce at least 77 million liters bioethanol and 74 million liters of biodiesel in 2020 (UNIDO 2016). The biogas production technology is not yet well developed in Cameroon. However, there is domestic and artisanal production of biogas in some parts of the country, like the North where in 2011 the Cameroonian Society of Hygiene and Sanitation (HYSACAM) inaugurated its first biogas production plan, and it was based on household waste (Erasmus et al. 2018).

There is no information on research on biogas technology in Cameroon, although a number of digesters have been installed in the country. In addition, published works on laboratory biogas digesters is not known. There is no data available on the amount of methane produced from installed biogas digesters or on ways to improve the quality of methane produced. In addition, research on biogas technology by biogas specialists is hampered by lack of funds, which has a negative impact on biogas programs in the country. Table 5 gives the potential of agricultural biomass residues available in Cameroon (Ngnikam et al. 2016).

\subsubsection{Crop and livestock farming in Cameroon as sources of clean energy, social justice and women's empowerment}

Cameroon's natural environment makes it possible to divide the country into three major areas of agricultural concentration: the northern zone and Adamaoua, the western highlands and the southern forest. By possessing all the geographical, and climatic zones, and the vegetation that is found on the African continent, Cameroon is often called Africa in miniature (Ngnikam et al. 2016). The government, through the Ministry

Table 4 Most polluting sectors in Cameroon. Source: TIPEEE-CAM

\begin{tabular}{|c|c|c|c|c|c|}
\hline $\mathrm{N}^{\circ}$ & Activity & $\mathrm{CO}_{2}(\mathrm{Gg})$ & $\mathrm{CH}_{4}(\mathrm{Gg})$ & $\mathrm{N}_{2} \mathrm{O}(\mathrm{Gg})$ & $\begin{array}{l}\text { TOTAL } \\
\text { (Gg } \mathrm{CO}_{2} \\
\text { eq. })\end{array}$ \\
\hline 1 & Combustion of fuels & 3983.0 & 141.8 & 2.0 & 7584.4 \\
\hline 2 & Energy industries & 1383.8 & 0.9 & 0.1 & 1438.9 \\
\hline 3 & $\begin{array}{l}\text { Manufacturing and con- } \\
\text { struction industries }\end{array}$ & 71.0 & 0.0 & 0.0 & 71.0 \\
\hline 4 & Transport & 2163.9 & 0.0 & 0.0 & 2169.3 \\
\hline 5 & Other sectors & 364.2 & 141.0 & 1.9 & 3905.2 \\
\hline \multirow[t]{2}{*}{6} & Oil and gas & 0.0 & 0.7 & 0.0 & 14.5 \\
\hline & Total Emissions & 3983.0 & 142.5 & 2.0 & 7598.9 \\
\hline
\end{tabular}


Table 5 Potential of agricultural biomass residues available in Cameroon

\begin{tabular}{lll}
\hline Crop & Residues & Annual capacity \\
\hline Rubber & Timber & $123,000 \mathrm{~m}^{3} /$ tonne \\
Cotton & Cotton/seed cake & 147,642 tonne $/ 45,780$ tonne \\
Robusta coffee & Chaff & 145,900 tonne \\
Sugar Cane & Bagasse/molasses & 244,750 tonne $/ 32,040$ tonne \\
Palm oil & Stalks/palm kernel shell & 57,695 tonne $/ 28,847$ tonne \\
\hline
\end{tabular}

of Agriculture and Rural Development, intends to continue implementing an emergency plan to increase agricultural production. Cameroon produces mainly maize, millet, sorghum, cassava, macabo, taro, yams, sweet potatoes and potatoes. It is the largest producer of coffee and cocoa in Central Africa (Vintila et al. 2019). With regard to livestock, the country produces 7 million cattle annually, 8 million small ruminants, 2 million pigs and 50 million poultry. The agricultural sector remains a priority for the government in terms of coverage of domestic needs and fight against poverty (Tchatat 2014). Cameroon is often presented as the breadbasket of Central Africa. It enjoys great climatic diversity (equatorial climate, humid tropical and dry tropical) and an ecology that allows it to produce a varied range of agricultural commodities. The dynamism of Cameroonian agriculture makes it possible to satisfy the food needs of the local populations and some of those from the countries of the sub region (Chad, Republic of Central Africa, Gabon, Congo and Equatorial Guinea).

Despite the government's efforts in the agricultural sector, Cameroon faces a high cost of factors of production, in particular because of a supply of energy much lower than the domestic need would require. Yet the country produces annually billions of tons of waste from agricultural and agro-industrial activities and from hospitals that may solve huge problems associated with environmental pollution and low energy supply, by embarking upon biogas production. While contributing to the reduction of the energy deficit and the creation of numerous employment opportunities, the exploitation of these renewable energies or biofuels would constitute new outlets to ensure an important source of income in the whole country.

Livestock farming deserves a particular attention, since it is not only one among the sources of materials to be used for the production of biogas, but also an activity which has created the conditions for the empowerment and emancipation of a relevant number of women in Cameroon. Since the 1980s, indeed, a severe economic crisis negatively affected many families, whose men decided to go to the big cities to look for a job in the urban context. After this, women had to take care of livestock farming, activity in which they had been previously involved only as assistant of their husbands. This job represented the possibility for women to earn the necessary resources for themselves and for their families, and of course it turned into an opportunity to build their own emancipation. Nowadays, livestock farming is mainly managed by women (Kam Kah 2013). This result opens a series of very interesting scenarios about the creation of new projects involving livestock farming as a source for the production of biogas: Projects may involve a wide protagonism of local women, whose empowerment would be not only related to their economic independence, but also to the creation of a virtuous alternative to fossil energy. 


\section{Discussion}

\subsection{Biogas production: challenges and economic benefits for the actors within a circular economy framework}

This section describes the benefits of biogas in a circular economy framework. Biogas is the center of an ecologically based economy that is emerging in China and may spread to several countries of the world. While the agricultural economy intensifies, there are still many farms, of large or medium sizes, in the suburbs of large cities. The multifunctionality in the use of biogas includes the waste treatment, the protection of the environment by reducing emissions of greenhouse gases, the generation of electricity, heat and gaseous biofuels. Anaerobic digestion can break down a multitude of organic wastes to produce biogas, and a wide range of other products, thereby, contributing significantly to the circular economy. Restorative and generative structure of circular economy aims at maintaining the products and materials they use and their maximum value at any time of the cycle (Sariatli 2017). Figure 7 shows the main concept of circular economy. The circular pattern around a biogas plant is shown in Fig. 8. Biogas production is the last stage of anaerobic digestion of the raw material, in which a renewable energy vector (biogas) is produced together with a digestate, to be used as a biofertilizer. Therefore, biogas production is a way to recycle waste for added value.

Without a biogas production scenario, the traditional model is set on the use of wastes coming from agricultural and livestock farming activities to fertilize the land; the rest of manure and other materials is considered to be disposed of, thus creating a cost for the household or the firm from which the material is originated (Yazan et al. 2018). Within a circular economy scenario in which manure and agricultural wastes are used to produce biogas and digestate as fertilizer, there are benefits not only for the preservation of environmental resources, due to the fact that the energy which is produced is alternative to fossil energy, but also for the economic incomes of both the farmer and the biogas producer. Of course some variables like the distance between the farm and the biogas plant, the dimension of both the structures and other elements may affect the positivity of this income (Yazan et al. 2018). A study has shown that cooperation between the two actors represent the best solution in terms both of environment preservation and economic benefit (Yazan et al. 2018).

LINEAR ECONOMY

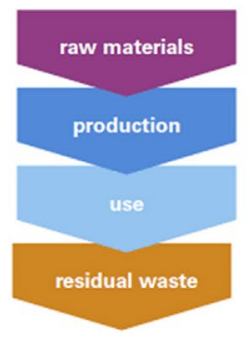

ECONOMY WITH FEEDBACK LOOPS

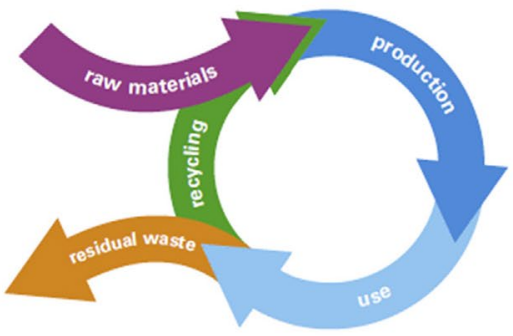

CIRCULAR ECONOMY

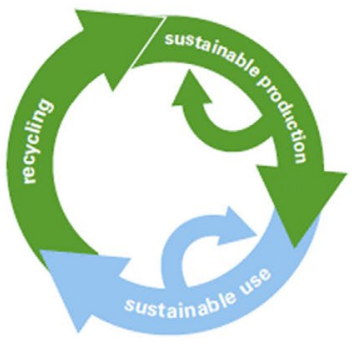

Fig. 7 Life cycle stages in the linear, recycling and circular economy models (Van Buren et al. 2016) 


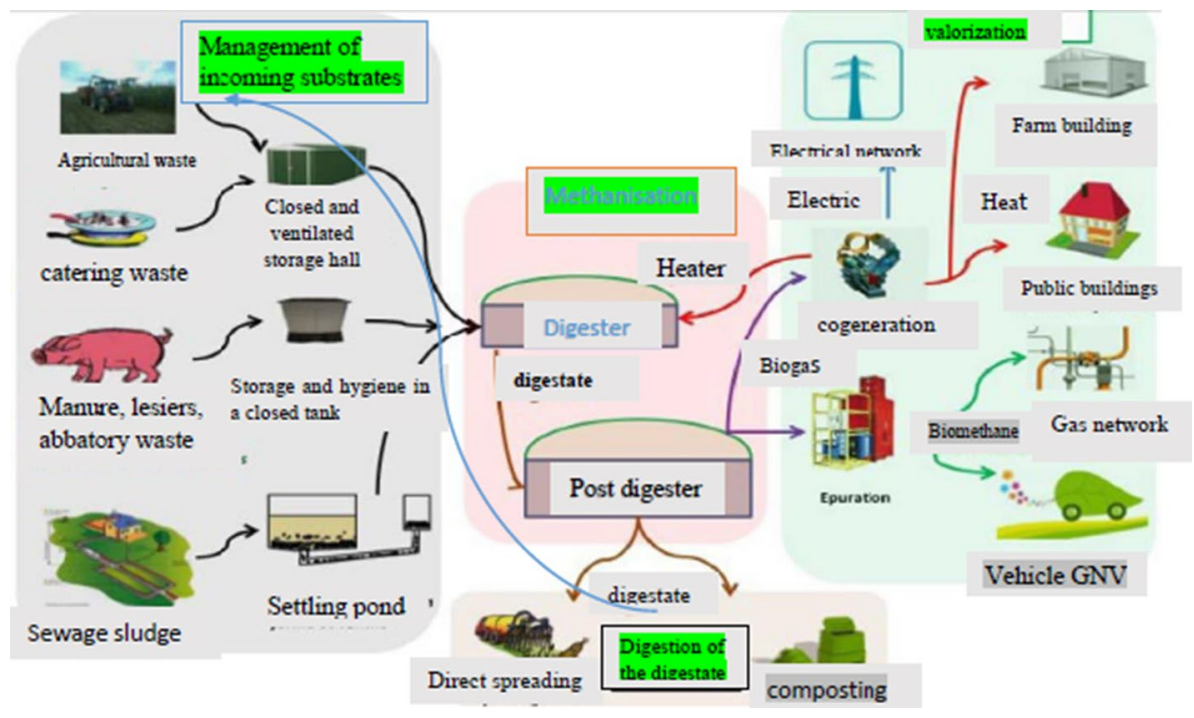

Fig. 8 Functions of biogas in the circular economy (ADEME 2013)

\subsection{Biogas as a basis for energy independence of a country}

Fossil energy is still widely used around the world. It derives from coal, petroleum and natural gas reserves which are located in relatively small geographical areas. Hence, many countries depend on a small number of fossil fuel exporting countries for their energy supply. Substituting these fossil fuels with some biological/renewable energy types would better balance the energy supply situation around the world, thereby making countries and regions more energy self-sufficient. Biogas production is becoming more reassuring for any municipality to become more energy independent and for the different local industries to benefit from greater energy production themselves. Centralized energy production systems are more sensitive to the risk of interruption of energy distribution in the event of storms or other natural events (Fagerström et al. 2018). Faced with these instabilities, the energy supply of the second world economy, China, is very far from being assured because China depends heavily on oil and gas imports from the Middle East and Africa. To ensure the country's economic growth, Beijing has to cover growing energy needs. Becoming increasingly dependent on imports, a sense of deep anxiety has raised among Chinese leaders, together with the fear that the country's economic growth could be slowed down by potential supply disruptions and unpredictable price increases. Biogas generation of electricity could balance energy production when the networks are vulnerable, for example during major weather events (Persson et al. 2014).

\subsection{Advantages of biogas for the environment: perspectives for next future's countries' policies}

Cameroon is a country which is projected as an emerging country by 2035 (EB 2019). Therefore, a trajectory will be built concerning its energy policy, in particular 
bioenergy, to ensure sustainable development. To reduce global warming, the Chinese authorities are putting priority in reducing greenhouse gas emissions. China has been the world's largest producer and consumer of coal since the early 1980s, accounting for nearly half of the global market. China's dependence on this energy source, with the exploitation of nearly 12,000 mines, largely explains the country's high greenhouse gas emissions and pollution problems, of course also coupled with its large population. The country accounts for $28 \%$ of $\mathrm{CO}_{2}$ emissions worldwide, according to the International Energy Agency (IEA 2019). To solve this problem, China must invest heavily in renewable sources of energy among which, of course, biogas may play an important role. Increased energy efficiency and China's goal of increasing environmental sustainability is expected to result in a smaller share of coal importation (Wang and Kaare 2019). In the last years, the Chinese government increased its attention to the questions of environment and green energy and promulgated a law called "law on the protection of the environment." Further, the development of bioenergy is requested to be an important goal in China's 13th Five-Year Plan (Liu et al. 2015). All of this should translate into good prospects for the Chinese biogas industry.

\subsubsection{Reduction of greenhouse gas (GHG) emissions from fossil sources}

Disposing of agricultural waste by means of open fires after the harvest season releases various greenhouse gases and fine substances into the atmosphere that contribute to the problem of global warming and air pollution (Almomani and Bhosale 2020). Biogas is considered a "cleaner" household fuel because it does not contribute to air pollution compared to fossil fuel (Poushali and Milind 2020). Biogas production may have a significant impact on reducing GHG emissions (Liebetrau et al. 2017). This reduction is the main challenge of switching from fossil fuels to renewable energies. The use of biogas has a beneficial consequence on the greenhouse effect: It makes it possible to burn the methane produced during the fermentation of the waste and thus prevent additional greenhouse gas with very high climate change potential from being produced from fossil fuels and released to the atmosphere. The rationale of this process is the observation that it is impossible to prevent the production of methane because of agricultural and especially livestock production all day long. Since methane global warming potential is 25 times higher than $\mathrm{CO}_{2}$, it is scandalous to release it into the atmosphere (Fagerström et al. 2018).

Biogas from anaerobic digestion is a multifunctional technology that offers solutions, particularly for the treatment and management of digestible waste from crops and animal origin, manure and sewage. A study by the French Environment and Energy Management Agency (ADEME) predicts that by 2020, biogas will contribute to a significant reduction in fossil greenhouse gas emissions (ADEME 2006). The estimate of this reduction in greenhouse gases is 751,000 tons of $\mathrm{CO}_{2}$ equivalent. The use of manure as raw material for anaerobic digestion reduces $\mathrm{CH}_{4}$ emissions generated from the storage and use of manure itself. Practically, this can lead to carbon-negative energy and fuels, because the $\mathrm{CO}_{2}$ emitted during the combustion of biogas has a lower global warming potential than methane emitted into the atmosphere from fossil fuel (Murphy et al. 2004). The use of biogas also makes it possible to reduce greenhouse gas emissions in accordance with the Kyoto protocol (Singh et al. 2017). However, subtracting manure to agricultural use will lead to an increased use and production of chemical fertilizers, causing environmental damage in their generation and application. 


\subsubsection{Carbon dioxide sequestration potential by the anaerobic fermentation process}

A major advantage of the use of biogas is the possibility to uptake and sequester $\mathrm{CO}_{2}$, in order to keep the global temperature below $1.5^{\circ} \mathrm{C}$ (EASAC 2018). For the sake of clarity, the methane obtained during the digestion process is accompanied by about $30 \%$ of carbon dioxide. When biogas is recovered as a biofuel in transport, $\mathrm{CO}_{2}$ must be separated from the $\mathrm{CH}_{4}$. Future energy systems, within a circular economy perspective, may use the $\mathrm{CO}_{2}$ released as raw material for food and biomaterials production. It could, for example, be used to increase the concentration of carbon dioxide in greenhouses (when its purity is high), thereby increasing crop and food production. It could also be used as a support in cooling systems or as a raw material for chemical production. Pure carbon dioxide could also be used in the food industry for the production of sparkling water and in breweries to add carbonated bubbles to beer.

To produce microalgae in closed-loop systems, significant amounts of carbon dioxide are captured from biogas and then converted into biomethane (Xia et al. 2015). The production of biogas on a domestic scale in Africa has contributed to the reduction of respiratory and eye diseases linked to the use of firewood or charcoal, an improvement of the living environment of households through better management of cow dung and domestic wastewater, in particular by connecting toilets to biodigesters.

\subsection{Water purification through anaerobic digestion implementation}

Water is a common national heritage which the State will have to protect and carefully manage, and make easily accessible to the population. In Cameroon, $53 \%$ of households are exposed to diseases carried by water through the use of wells for drinking. Similarly, China has considerable water resources, but given the size of its population (about 1.3 billion), availability per capita is very limited. Water pollution is becoming a widespread phenomenon in the cities and countryside of some riverine areas due to major works of heavy industrialization in the country, the accelerated and uncontrolled suburbanization ( $\mathrm{Lu}$ and Zhongguo 2000).

Anaerobic digestion is an effective method of reducing high biological oxygen demand (BOD) in the effluents. Biological oxygen demand is a measure of the amount of oxygen used by microorganisms during the biochemical oxidation of the organic matter. For example, wastewater from dairy products have high BODs; with values being as high as 25 to 40 times more than that in domestic wastewater. About $70 \%$ to $90 \%$ of it can be removed by anaerobic processes at a lower cost, when compared to aerobic systems.

The production of biogas on a domestic scale in Africa has contributed to the reduction of respiratory and eye diseases linked to the use of firewood or charcoal, an improvement of the living environment of households through better management of cow dung and domestic wastewater, in particular by connecting toilets to biodigesters.

\subsection{Agricultural waste management and energy generation in an anaerobic digestion framework}

Thanks to anaerobic digestion, farmers will be able to reduce their greenhouse gas emissions, store and process their waste, diversify their activities and thus secure a portion of their income by reselling the energy they have produced. The use of biogas digestate for soil fertilization significantly reduces the use of chemical fertilizers. The minerals present 
in the substrates are conserved, and the predominantly organic nitrogen in the raw manure effluents becomes mainly mineralized in the digestates. It is thus more easily assimilated by plants, and water pollution is reduced. The use of digestates in the rural areas significantly reduces odors and flies that result from the use of raw slurry, thereby greatly improving on the quality of air and life in the areas. An article (Gobar Gas 2018) in the Nepal Times points out that the successful biogas program in Nepal not only has provided farmers with clean fuel, but has also helped conserve forests and provide high quality fertilizer for their crops; the result is a worldwide repayment, to avoid the burning of firewood, which releases carbon dioxide $\mathrm{CO}_{2}$ [a greenhouse gas] into the atmosphere (Kandal 2002). Multifunctional uses of biogas bring cross-benefits in the areas of energy, transport, agriculture and waste management, as well as in all sectors of the environment and climate (AL Seadi et al. 2018). In Africa and China, we can observe farmers in the agricultural field who have adopted the biodigester based on an integration of livestock and agriculture by valuing the by-products from these two activities (valuation of millet stalks and other agricultural wastes for the production of animal feed; production of organic manure for the soil).

To summarize, the multifunctional uses of biogas produce savings in: (1) the production of biofuels and renewable energies; (2) the reduction of greenhouse gas emissions $\left(\mathrm{CH}_{4}, \mathrm{CO}_{2}\right)$; (3) the reduction of nuisances due to odors and flies; (4) financial savings for farmers; (5) sustainable treatment and recycling of organic waste; (6) the reduction of air and water pollution; (7) the improvement of local and rural economies; the improvement of social conditions, among which gender balance has a particular importance. Figure 9 shows the process of producing biogas from agricultural waste.

\section{Conclusions}

The use of biogas as renewable energy has excellent prospects. An important factor in encouraging the spread of biogas technology is the establishment of an appropriate legal framework. For example, in March 1999, Germany carried out a major tax reform which established taxes on energy sources and carbon emissions, while having a tax exemption on the use of renewable energy sources.

To maximize the benefits of biogas as a source of energy, China surely needs to incorporate advanced technologies for purifying and compressing methane, and it needs to build new engines that work effectively and efficiently using methane. Such policies may contribute

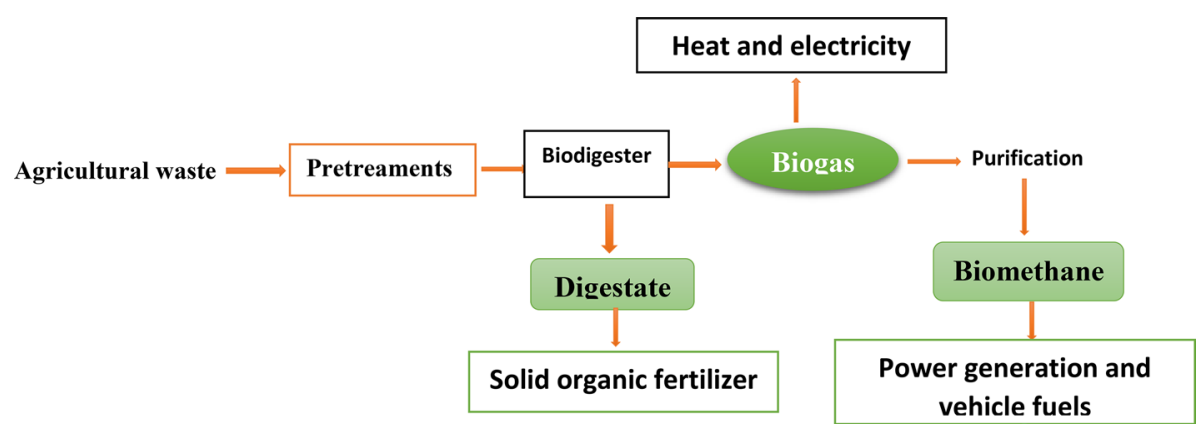

Fig. 9 Detailed mechanism of the biogas production from agricultural waste (Liu et al. 2011) 
to making green energy profitable and are crucial to the ultimate success of green energy programs.

Anaerobic digestion allows the production of renewable and efficient energy, while improving the environmental performance of farms. It helps to reduce chemical fertilizers and improve soil quality. China, just as Cameroon and many other African countries, has an abundance of resources from agricultural activities which are largely untapped. The use of these biological resources will grow in absolute and relative terms in the coming years. In an effort to attain a sustainable development, this waste can be transformed by biotechnological methods for producing renewable energy. They can contribute significantly to reducing greenhouse gas emissions, for the improvement of soil fertility, and for the reduction of deforestation in Africa by offering an alternative fuel to wood for various applications such as cooking and heating, thereby ensuring a sustainable environment and bringing in potential financial and social gains for the local population.

In addition to all this, as already said several times above, the introduction of a wider, more solid and independent program of biogas plants installation may represent the opportunity for many African countries to avoid both the dependence from coal—mainly coming from China-and from European capitals investing and gaining profits from the local renewable sources of energy.

Acknowledgements This research was supported by the Geography Faculty of the Beijing Normal University through the 2019 Short Program Course on Resources and Environmental Management. The authors would like to thank all the people who supported this study. Sergio Ulgiati and Serena Kaiser also acknowledge the funding from the European Union's Horizon 2020 Research and Innovation Programme under the Marie Skłodowska-Curie Innovative Training Networks (H2020-MSCA-ITN-2018) scheme, Grant Agreement Number 814247 (ReTraCE project).

Funding Open access funding provided by Università Parthenope di Napoli within theCRUI-CARE Agreement. This research was supported by the Geography Faculty of the Beijing Normal University through the 2019 Short Program Course on Resources and Environmental Management. The authors would like to thank all the people who supported this study. Sergio Ulgiati also acknowledges the funding from the European Union's Horizon 2020 Research and Innovation Programme under the Marie Skłodowska-Curie Innovative Training Networks (H2020-MSCA-ITN-2018) scheme, Grant Agreement Number 814247 (ReTraCE project).

\section{Compliance with ethical standards}

Conflicts of interest The authors declare that they have no known competing financial interests or personal relationships that could have appeared to influence the work reported in this manuscript.

Consent to participate All authors have been allowed by their affiliation organizations to collaborate to this manuscript.

Consent for publication All authors have been allowed by their affiliation organizations to submit this manuscript.

Availability of data and material Appropriate reference was given for all the data used in the submitted manuscript. However, authors remain available to further clarifications if contacted by interested readers.

Ethical approval The authors declare that there are no ethical conflicts associated with the submitted manuscript.

Open Access This article is licensed under a Creative Commons Attribution 4.0 International License, which permits use, sharing, adaptation, distribution and reproduction in any medium or format, as long as you give appropriate credit to the original author(s) and the source, provide a link to the Creative Commons 
licence, and indicate if changes were made. The images or other third party material in this article are included in the article's Creative Commons licence, unless indicated otherwise in a credit line to the material. If material is not included in the article's Creative Commons licence and your intended use is not permitted by statutory regulation or exceeds the permitted use, you will need to obtain permission directly from the copyright holder. To view a copy of this licence, visit http://creativecommons.org/licenses/by/4.0/.

\section{References}

ADEME. (2006). Les installations de traitement des ordures ménagères. Agence de l'Environnement et de la Maitrise de l'Energie, pp. 1-8.

Ademe. (2013). L'évaluation macroéconomique des visions énergétiques 2030-2050 de l'ADEME, pp 13-65.

Adeniyi, O. D., Kovo, A. S., Abdulkareem, A. S., \& and. Chukwudozie, . (2007). Production from Cassava as a substitute for gasoline ethanol fuel. Journal of Dispersion Science and Technology, 28, 501-504. https://doi.org/10.1080/01932690701276940.

Almomani, F. (2020). Prediction of biogas production from chemically treated co-digested agricultural waste using artificial neural network. Fuel, 280, 118573.

Almomani, F., \& Bhosale, R. (2020). Enhancing the production of biogas through anaerobic co-digestion of agricultural waste and chemical pre-treatments. Chemosphere. https://doi.org/10.1016/j.chemospher e.2020.126805.

Almomani, F., Bhosale, R. R., Khraisheh, M. A. M., \& Shawaqfah, M. (2019). Enhancement of biogas production from agricultural wastes via pre-treatment with advanced oxidation processes. Fuel, 253, 964-974.

Al Seadi, T., Stupak, I., \& Smith, C. T. (2018). In J. D. Murphy (Ed.), Governance of environmental sustainability of manure-based centralised biogas production in Denmark (Vol. 37, p. 7). IEA Bioenergy Task.

Amigun. B., Parawira. W., Musango. J. K., Aboyade. A. O. and Badmos. A. S. (2012). Anaerobic biogas generation for rural area energy provision in Africa, Biogas, Dr. Sunil Kumar (Ed.), ISBN: 978-95351-0204-5, InTech, Retrieved 2012 from http://www.intechopen.com/books/biogas/anaerobic-bioga s-generation-for-rural-areaenergy-provision-in-africa.

Amigun, B., Sigamoney, R., \& Von Blottnitz, H. (2008). Commercialisation of biofuel industry in Africa: A review. Renewable and Sustainable Energy Reviews, 12, 690-711. https://doi.org/10.1016/j. rser.2006.10.019.

Ayhan, D. (2008). Importance of biomass energy sources for Turkey. Energy Policy, 36, 834-842. https:// doi.org/10.1016/j.enpol.2007.11.005.

Bargigli, S., Cigolotti, V., Pierini, D., Moreno, A., Iacobone, F., \& Ulgiati, S. (2010). Cogeneration of heat and electricityA comparison of gas turbine, internal combustion engine and MCFC/GT hybrid system alternatives. Journal of Fuel Cell Science and Technology, 7(1), 0110191-0110196.

Bertrand, F., \& Rocher, L. (2007). Le changementclimatique, révélateur des vulnérabilitésterritoriales ?Université de Tours, UMR CITERES, rapport de recherche pour le Bilan et analyse des outilsd'évaluation des politiquespubliques locales en France: de l'émergence d'un changementdans les modes de faire au défi d'un changementdans les modes de penser. Thèse de Doctorat, Science et génie de l'environnement. Monnet, St Etienne, France: Ecole des Mines de St Etienne-Université J.

Chen, W., Dollar, D., Tang, H., (2018). Why is China investing in Africa? Evidence from the firm level. Published by Oxford University Press on behalf of the World Bank. (C) World Bank. Retrieved from https://openknowledge.worldbank.org/handle/10986/33529 License: CC BY-NC-ND 3.0 IGO.

Chi, T., Zuo, J., \& Liu, F. (2017). Performance and mechanism for cadmium and lead adsorption from water and soil by corn straw biochar. Frontiers of Environmental Science \& Engineering. https://doi. org/10.1007/s12182-016-0105-6.

Clemens, H., Rob, B., Anne, N., \& Victoria, N. (2018). Africa biogas partnership program: A review of clean cooking implementation through market development in East Africa. Energy for Sustainable Development. https://doi.org/10.1016/j.esd.2018.05.012.

Cyimana, M., Qichun, H., Ke, P. (2013). Dissemination and problems of African biogas technology, Energy and Power Engineering, 5, pp 506-512 http://dx.doi.org/https://doi.org/10.4236/epe.2013.58055 (http://www.scirp.org/journal/epe).

Deng, L., Liu, Y., Zheng, D., Wang, L., Pu, X., Song, L., et al. (2017). Application and development of biogas technology for the treatment of waste in China. Renewable and Sustainable Energy Reviews, $70(\mathrm{C}), 845-851$. 
EASAC (2018). European Academies Science Advisory Council. Negative Emission Technologies: What role in meeting Paris Agreement targets? Retrieved from https:// easac.eu/publications/details/ easac -net/.

EB. (2019). Republic of Cameroon country strategic opportunities programme 2019-2024: Review.

EDE. (2013). Technical and economic-financial review of Biogas installations in Senegal, (Senegal), September 2013, 77 Pages.

Erasmus, M., Sofiane, A., \& Fouzi, Ta. (2018). Sustainable energy policies in Cameroon: A holistic overview. Renewable and Sustainable Energy Reviews, 82, 3420-3429.

Erin, V. (2019). Covanta reports progress with UK waste-to-energy projects; Retrieved from http://bioma ssmagazine.com/uploads/posts/web/2019/07/CovantaQ22019_15644400178483.jpg

État des VillesAfricaines. (2010). Gouvernance, inégalité et marchésfonciersurbains (pp. 123-156). Nairobi: Programme des Nations unies pour les établissementshumains.

EUEI-PDF (2013). Country power marker brief: Cameroon. Euei Pdf 2013:1 -5. Retrieved 20 Aug 2016

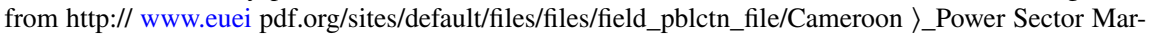
ket Brief_Dec2013_EN.pdf.

Fagerström, A., Al Seadi, T., Rasi, S., \& Briseid, T. (2018). In J. D. Murphy (Ed.), The role of anaerobic digestion and biogas in the circular economy (Vol. 37, p. 8). IEA Bioenergy.

Florio, C., Fiorentino, G., Corcelli, F., Ulgiati, S., Dumontet, S., Güsewell, J., \& Eltrop, L. (2019). A life cycle assessment of biomethane production from waste feedstock through different upgrading technologies. Energies, 12, 718.

Francis, K., Muyiwa, S., \& Adaramola., John, M. . (2018). A review of commercial biogas systems and lessons for Africa. Energies, 11, 29-84. https://doi.org/10.3390/en11112984.

Gobar gas the benefits of gas from dung (2018). Retrieved from https://blog.anaerobic-digestion.com/gobar -gas-benefits/.

He, G., Bluemling, B., \& Mol, A. (2013). Comparing centralized and decentralized bio-energy systems in rural China. Energy Policy., 63, 34-43.

Hengeveld, E. J., Bekkering, J., Van Gemert, W. J. T., \& Broekhuis, A. A. (2016). Biogas infrastructures from farm to regional scale, prospects of biogas transport grids. Biomass and Bioenergy, 86, 43-52.

IEA, 2018. World Energy Outlook, ISBN 978-92-64-30677-6.

IEA (2019). Retrieved Feb 2020 from https://www.iea.org/data-and-statistics/.

Jegede, A. O., Zeeman, G., \& Bruning, H. (2019). A review of mixing, design and loading conditions in household anaerobic digesters. Critical Reviews in Environmental Science and Technology. https://doi. org/10.1080/10643389.2019.1607441.

Jiang, X., Sommer, S. G., \& Christensen, K. V. (2011). A review of the biogas industry in China. Energy Policy., 39, 6073-6081.

John, A. M., \& Hao, T. (2016). China's renewable energy revolution: what is driving it? Nature, 36, 834-842.

Joseph, M. N., Lennart, B., \& Erik, O. A. (2019). Benefits and challenges to productive use of off-grid rural electrification: The case of mini-hydropower in Bulongwa-Tanzania. Energy for Sustainable Development, 53, 97-103.

KamKah, H. (2013). GENDER and Livestock Farming in Laimbweland, Cameroon, 1980S-2011. Journal of Sustainable Development in Africa, 15(1), 56-72.

Kandal, R.K. (2002). Biogas technology: Experiences in India. Proc. Intel. Seminar in biogas technology for rural - mountainous development and urban areas, Hanoi, Vietnam, Jan 2002.

Kaparaju, P., Rintala, J. (2013). Generation of heat and power from biogas for stationary applications: boilers, gas engines and turbines, combined heat and power (CHP) plants and fuel cells. In Wellinger, A., Murphy, J., Baxter, D., (Eds.), the biogas handbook: Science, production and applications. Woodhead Publishing series in energy: number 52, ISBN 978-0-85709-498-8.

Kemausuor, F., Adaramola, M., \& Morken, J. (2018). A review of commercial biogas systems and lessons for Africa. Energies., 11, 2984. https://doi.org/10.3390/en11112984.

Lei, G., Yi-Xin, Z., Jian-Zhou, W., Gina, C., \& Hugh, B. (2016). Where is the future of China's biogas? Review, forecast, and policy implications. Journal on petroleum science and technology, 13, 604-624.

Lei, Z., Jingang, C., Mingyue, Z., Shikun, C., Li-Pang, W., Heinz-Peter, M., \& Zifu, L. (2020). What could China give to and take from other countries in terms of the development of the biogas industry? Sustainability, 12, 1490. https://doi.org/10.3390/su12041490.

Li, N., Zhong, Q., \& Huan, W. (2014). Medical waste management in China: A case study of Xinxiang. Journal of Environmental Protection, 5, 803-810. https://doi.org/10.4236/jep.2014.510082.

Liebetrau, J., ReineL, T., Agostini, A., \& Linke, B. (2017). In J. D. Murphy (Ed.), Methane emissions from biogas plants: Methods for measurement, results and effect on greenhouse gas balance of electricity produced (Vol. 37, p. 12). IEA Bioenergy Task. 
Lifan, Li (2016). Energy Security and Energy Risk Management, Journal of International Affair, retrieved from file="http://blogs.cuit.columbia.edu/jia/files/2016/03/Li_EnergySecurity.pdf.

Liu, H., Jiang, M., Zhuang, H., \& Wang, J. (2008). Distribution, utilization structure and potential of biomass resources in rural China: With special references of crop residues. Renewable and Sustainable Energy Reviews, 12, 1402-1418.

Liu, X., Yan, Z., \& Yue, Z.-B. (2011). Biogas. Biofuels and Bioenergy, 3(2011), 99-114. https://doi. org/10.1016/B978-0-08-088504-9.00165-3.

Lohri, C. R., Diener, S., Zabaleta, I., Mertenat, A., \& Zurbruegg, C. (2017). Treatment technologies for urban solid biowaste to create value products: A review with focus on low- and middle- income settings. Reviews in Environmental Science and Bio/Technology, 16, 81-130. https://doi.org/10.1007/s11157-017-9422-5.

Liu H, Cui J, Chen Y. (2015). Ouverte pour obtenir des conseils, la Chine prévoit un développement environnemental au stade antérieur de la «13e période quinquennale». 2015. http://news.xinhuanet.com/ (en chinois).

Lu, D., Zhongguo, B. (2000). [Rapport sur le développement régional de la Chine], Pékin 2000.

Lynd, L. R., Sow, M., Chimphango, A. F. A., Cortez, L. A. B., Cruz, C. H. B., Elmissiry, M., et al. (2015). Bioenergy and African transformation. Biotechnology for Biofuels, 8, 1-18.

María, M. (2018). China’s energy security strategies - analysis. Eurasia Review: News \& Analysis.https://www. eurasiareview.com/22012017-chinas-energy-security-strategies-analysis/.

Minh, D. P., Siang, T. J., Vo, D.-V.N., Phan, T. S., Ridart, C., Nzihou, A., \& Grouset, D. (2018). Hydrogen production from biogas reforming: An overview of steam reforming, dry reforming, dual reforming, and tri-reforming of methane. In A. Azzaro-Pantel (Ed.), Hydrogen supply chains. Design deployment and operation. Cambridge: Academic Press.

Ministry of Energy and Water Resources Cameroon (2010). National biogas programme. Blue flame for brighter future for Cameroon. Cameroon: Ministry of Energy and Water Resources.

Mohammed, A., Kabbashi, F, M, A., Hamad, H, K, A. (2017). Production of biogas from biomedical waste (blood). A Research Submitted in Partial fulfillment for the Requirements of the Degree of B.Sc. (Honors) in Biomedical Engineering. Sudan University of Science and Technology College of Engineering, Biomedical Engineering Department.

Mshandete, A. (2009). Biogas technology research in selected Sub-Saharan African countries-A review. African Journal of Biotechnology, 8, 116-125.

Mshandete, A., \& Parawira., W. . (2009). Biogas technology research in selected Sub Saharan Africa. African Journal of Biotechnology, 8, 116-125.

Murphy, J. D., Mckeogh, E., \& Kiely, G. (2004). Technical/economic/environmental analysis of biogas utilisation. Applied Energy, 77, 407-427.

Mus'ud, A.A., Wirba, A.V., Firdaus, M.S., Mas'ud, I.A., Munir, A.B., Yunus, N.M. . (2015). An assessment of renewable energy readiness in Africa: Case study of Nigeria and Cameroon. Renewable and Sustainable Energy Reviews, 51, 775-784.

Ngnikam, E., Hofer, A., Kraft, D. (2016). Renewable energy in West Africa: country chapter, Cameroon. Federal Ministry of Economic Cooperation and Development; 49, 38-51. Retrieved 20 Aug 2016 from https:// www.agcc.co.uk/ uploaded_files/Renewable Reports - BMZ.pd.

Nixon, J. D., Dey, P. K., \& Ghosh, S. K. (2017). Energy recovery from waste in India: an evidence- based analysis. Sustainable Energy Technologies and Assessments, 21, 23-32.

Ocwieja, S.M. (2010). Life Cycle Thinking Assessment Applied to Three Biogas Projects in Central Uganda, being a Report Submitted in Partial Fulfillment of the Requirements for the Degree of Master of Science in Environmental Engineering, Michigan Technological University, pp 231-245.

Pan, W., Hongtao, W., Yinquan, Q., Lianhai, R., \& Bin, J. (2018). Microbial characteristics in anaerobic digestion process of food waste for methane production-A review. Bioresource Technology, 248, 29-36.

Patrick, M., Golden, M., \& Sampson, M. (2016). Biogas technology in South Africa, problems, challenges and solutions. International Journal of Sustainable Energy and Environmental., 5, 58-69. https://doi. org/10.18488/journal.13/2016.5.4/13.4.58.69.

Persson, T., Murphy, J.D., Jannasch, A.M., Ahern, E., Liebetrau, J., Trommler, M., Toyama, J. (2014). A perspective on the potential role of biogas in smart energy grids. International Energy Agency, Task 37, ISBN 978-1-910154-13-7 (eBook electronic edition). Retrieved from http://task37.ieabioenergy.com/files/ datenredaktion/download/Technical\%20Brochures/Smart_Grids_Final_web.pdf.

Poushali, M., \& Milind, K. (2020). Quantifying the air quality, climate and equity implications of India's household energy transition. Energy for Sustainable Development, 55, 37-47.

Renewable Energy Network of the 21st Century (2018). Renewables 2018 Global Status Report. Retrieved 12 June 2018 from http://www.ren21.net/status-of-renewables/global-status-report/.

Renwick, M., Subedi, P., Hutton, G. (2007). Cost benefits analysis of national and regional integrated biogas and sanitation program in Sub-Saharan-Africa. WINROCK International Draft Final Report, Dutch Ministry 
of Foreign Affairs. Retrieved from http://www.susana.org/docs_ccbk/susana_download/2-59 6-renwick-etal-2007-cba-biogas-subsaharanafrica-en.pdf.

Rufis, T. T., Ioana, I., Anagho, S. G., \& Alin, C. (2019). Optimization of the activated carbon preparation from avocado seeds using the response surface methodology. REVISTA DE CHIME, 70, 410-416.

Sariatli, F. (2017). Linear economy versus circular economy: A comparative and analyzer study for optimization of economy for sustainability. Visegrad Journal on Bioeconomy and Sustainable Development, 6(1), 31-34. https://doi.org/10.1515/vjbsd-2017-0005.

Singh, D., Pachauri, S., \& Zerriffi, H. (2017). Environmental payoffs of LPG cooking in India. Environmental Research Letters, 12, 115003-115009. https://doi.org/10.1088/1748-9326/aa909d.

Susan, J., Ling, L., Deborah, B., Jinguang, H., Xu, Z., Tianwei, T., et al. (2016). In J. D. Murphy (Ed.), The potential of biofuels in China (Vol. 39, pp. 1-40). IEA Bioenergy Task.

Tchatat, G. (2014). Cameroun - contribution à la preparation du rapport national pour la formulation du livre blanc regional sur l'acces universel aux services energetiques integrant le developpement des energies renouvelables et de l'efficacite energetique, pp 231-256.

U.S. Environmental Protection Agency, Bio-based products and chemicals, waste-to-energy scoping analysis (2015). Office of Resource Conservation and Recovery.

Ukpabi, C. (2008). Biogas for better life, an African initiative. Retrieved 17 May 2011 from http://biogasafri ca.org/index.php?option=com_docman\&Itemid=16=en.

UNIDO (2016). United Nations Ind Dev. Organ. Cameroon: Biomass energy in Cameroon. Retrieved 11 Aug 2016 from http://www.unido.it/eng/biomassa.php.

United Nations (2015). The Paris Agreement, https://unfccc.int/process-and-meetings/the-paris-agreement/theparis-agreement.

USDA/FAS (2008). United States Department of Agriculture/Foreign Agricultural Service; World Report: Cattle population by country. Retrieved from http://www.cattlenetwork.com/templates/newsarchiv e.html?sid=cn\&cid=600361.

Van Buren, N., Demmers, M., Van der Heijden, R., \& Witlox, F. (2016). Towards a circular economy: The role of Dutch logistics industries and governments. Sustainability, 8(7), 647. https://doi.org/10.3390/ su8070647.

Van Nes, W. J. and T. D. Nhete (2007). Biogas for a better life: An African initiative. Renewable Energy World Magazine; 10-4 July/August.

Vintila, T., Ioana, I., Rufis, T., \& T., Adriana, R., Calin, J., Anagho, S, G. . (2019). Residual biomass from food processing industry in cameroon as feedstock for second-generation biofuels. BioResources, 14, 3731-3745.

Wall, D., Dumont, M., Murphy, J.D. (2018). Green gas: Facilitating a future green gas grid through the production of renewable gas. International Energy Agency (IEA) Bioenergy, 37, p 2. Retrieved from: http:// task37.ieabioenergy.com/files/datenredaktion/download/Technical\%20Brochures/green_gas_web_end. pdf.

Wang.Z \& · Kaare.S. . (2019). Thoughts on China's energy transition outlook. Energy Transitions., 3, 59-72. https://doi.org/10.1007/s41825-019-00014-w.

World Bank: Hebei Rural Renewable Energy Development Project. Retrieved from https://projects.worldbank. org/en/projects-operations/project-detail/p132873?lang=en\#abstract.

World Bank (2020): World perspective, Retrieved from https://perspective.usherbrooke.ca/bilan/tend/CHN/fr/ EN.POP.DNST.html, date of consultation: 6/22/2020.

Xia, A., Herrmann, C., \& Murphy, J. D. (2015). How do we optimize third-generation algal biofuels? Biofuels, Bioproducts and Biorefining, 9, 358-367.

Xuchuan, S., Xianglin, G., Jiane, Z., Yajiao, W., \& Mengyu, Z. (2018). A comparative study of thermophilic and mesophilic anaerobic co-digestion of food waste and wheat straw: Process stability and microbial community structure shifts. Waste Management, 75, 261-269.

Yang, L., Xu, F., Ge, X., \& Li, Y. (2015). Challenges and strategies for solid-state anaerobic digestion of lignocellulosic biomass. Renewable and Sustainable Energy Reviews, 44, 824-834.

Yazan, D. M., Cafagna, D., Fraccascia, L., Mes, M., Pontrandolfo, P., \& Zijm, H. (2018). Economic sustainability of biogas production from animal manure: a regional circular economy model. Management Research Review, 41(5), 605-624.

Yotchou, A. P. (2014). Les inégalités de genre en matière d'accès à la terre et de définition des politiques agricoles au Cameroun : Initiatives du CEFAP pour contribuer à l'accès à la terre des femmes rurales de Tonga dans la région de l'Ouest Cameroun. Communication dans le cadre du Colloque international genre et agricultures familiale et paysanne, regards Nord-Sud. Toulouse; Récupéré le 20 octobre 2014 du site Genre et action. Retrieved from http://www.genreenaction.net/IMG/pdf/Communication_Anne_Pelag ie.pdf. 
Zhang, P., \& Zhang, Y. (2014). Global bioenergy policy comparison and revelation. Journal of China University of Geosciences, 14, 93-99.

Zhang, W., Wu, S., Guo, J., Zhou, J., \& Dong, R. (2015). Performance and kinetic evaluation of semi-continuously fed anaerobic digesters treating food waste: Role of trace elements. Bioresource Technology, 178, 297-305.

Zucaro, A., Fiorentino, G., Zamagni, A., Bargigli, S., Masoni, P., Moreno, A., \& Ulgiati, S. (2013). How can life cycle assessment foster environmentally sound fuel cell production and use? International Journal of Hydrogen Energy, 38(1), 453-468.

Zumar, M., Bundhoo, D., \& S. . (2019). Evaluation of the potential of bio-methane production from fieldbased crop residues in Africa. Renewable and Sustainable Energy Reviews, 115, 109-357. https://doi. org/10.1016/j.rser.2019.109357.

Publisher's Note Springer Nature remains neutral with regard to jurisdictional claims in published maps and institutional affiliations.

\section{Authors and Affiliations}

\section{Rufis Fregue Tiegam Tagne ${ }^{1} \cdot$ Xiaobin Dong ${ }^{2} \cdot$ Solomon G. Anagho ${ }^{1} \cdot$ Serena Kaiser $^{3}$. Sergio Ulgiati ${ }^{3,4}$}

Rufis Fregue Tiegam Tagne

rufistagne@yahoo.fr

Solomon G. Anagho

sg_anagho@yahoo.com

Serena Kaiser

serekai83@gmail.com

1 Department of Chemistry, Research Unit of Noxious Chemistry and Environmental Engineering, Faculty of Science, University of Dschang, P.O. Box 67, Dschang, Cameroon

2 College of Resources Science and Technology, State Key Laboratory of Earth Surface Processes and Resource Ecology, Beijing Normal University, Beijing, China

3 Department of Sciences and Technologies, Parthenope University of Napoli, Napoli, Italy

4 School of Environment, Beijing Normal University, Beijing, China 